\title{
Impact of Perceived Deception on Consumer Behaviour: The Case of Detergent Powder
}

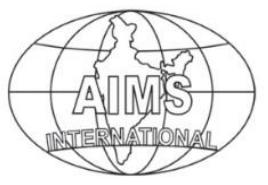

DOI: $10.26573 / 2020.14 .1 .2$

\author{
Ishpreet Virdi \\ Delhi University \\ (ishpreet2104@gmail.com)
}

Volume 14, Number 1

January 2020, pp. 11- 42

Advertising attempts to persuade potential customers to purchase or consume a product or service. Thus, advertising plays a very important role in forming consumer behaviour. But advertisements can be used as a means of deception also. Being misled by an advertisement, consumers may respond negatively to further advertising. This paper estimates the impact of exposure to deceptive advertising on consumption of the advertised product and its substitutes. This paper studies the market for washing products, in which deceptive advertising is rampant. Strengths of the paper include matching of specific advertisements to individual respondents based on their TV watching behaviour, quantification of the deceptiveness of ads based on explicit FTC guidelines for this product category, and various methods to control for targeting of ads. In reviewing the consumer behaviour literature and recent empirical work, a conceptual model of consumer behaviour was developed. A unique individuallevel data that includes consumption and television viewing has been assessed in this study. Respondents were asked to fill in questionnaire based on three types washing powders used by consumers. It is a repeated cross-sectional survey, in which, each wave is an independently drawn multistage stratified probability sample of females. Moreover, screenshots of these TV commercials were shown to help them in the recall. They were asked to report their view points on various questions regarding the purchase behaviour, their frequency of purchases on the bases of various attributes regarding the purchase decisions. Exposure to deceptive statements is then used to predict consumption, controlling for demographic factors and other variables used by marketers to target their ads. Using analysis, antecedent conditions of consumers' perceived deception and the behavioural effects of consumer perceived deception were explored. Implications for management and suggestions for further research are provided towards the end.

Keywords: Consumer Behaviour, Perceived Deception, Anova Analysis, Deceptive Advertising

\section{Introduction}

Undoubtedly, one reason for a lack of previous empirical research on the impact of deceptive advertising on consumption is the difficulty to define the term "deceptive." 
One advantage of studying the market for detergent powder is that the FTC has issued specific definitions of deception for this market (FTC, 2003, 2005). These definitions of deception seem reasonable. However, even if one disagrees with them, the FTC standards remain policy relevant because they are the official definitions of the relevant governing agency. Most of those researchers who study deception and its detection have made attempts to define the terms "deception" (Byrd Bredbenner, Grasso, \& Darlene, 2001), "lie" (Edell, 1983) or "deceptive communication" (Kuehl R. F., Jan., 1974), which will be used interchangeably in the paper. It is surprising to see how similar these definitions are to the average person's conception of deception. "Deception refers to introducing a false belief in another," (Heslop, Mar., 1985). According to Webster's Dictionary, to lie is "to assert something known or believed by the speaker to be untrue with intent to deceive" (Webster's Dictionary). The Oxford Concise Dictionary defines lie as "an intentionally false statement"; deception as "the act or an instance of deceiving" and deceiving as to "make (a person) believe what is false, mislead purposely" (Oxford Concise Dictionary).

For a communication to be deceptive, it is not sufficient that the communicator should give false information, but this must also be done intentionally. Nonintentional alterations are not considered to be criminal in terms of law. Law recognizes intentional alterations and punishes the crimes of false accusation and false testimony during a trial. In order to be accused of these crimes, what is important is not the success or failure of the deception, but the witness's purpose (intentionality) in deceiving. The problem is that often, the only person who knows whether the deceptive attempt is deliberate or not is the witness himself or herself.

Deceptive communication strives for persuasive ends; or, stated more precisely, deceptive communication is a general persuasive strategy that aims at influencing the beliefs, attitudes, and behaviour of others by means of deliberate message distortions ... successful deceit seldom represents the end sought by the communicator, but is rather the means toward another persuasive goal (Albers-Millers, 1999). (Armstrong, M., Metin N., \& Frederick A., 1980) conclude that there are four basic ways of altering information

1. Manipulating the amount of information offered,

2. Distorting the information offered,

3. Presenting the information in an equivocal or ambiguous fashion, and

4. Presenting information that is irrelevant to the preceding discourse.

Other factors underlying consumer deception behaviour suggested in the literature include

1. The penalty and sanctions associated with criminal behaviour,

2. Direct or indirect social pressure (whether the person is conducting illegal behaviour in the presence or absence of others),

3. Personality traits and characteristics of individuals, and

4. The ability of participants to rationalize the behaviour (Albers-Millers, 1999)

Common definitions of deception, as proposed by deception researchers, are listed below:

- "A communicator's deliberate attempt to foster in others a belief or understanding which the communicator considers to be untrue" (Cohen D., Winter 1982) (Beauchamp, 1984). 
- "A deliberate act perpetrated by a sender to engender in a receiver belief contrary to what the sender believes is true to put the receiver at a disadvantage" (Barens \& G, 1975). "A cognitive interaction between two parties in conflict of interest: a deceiver and a target. The deceiver manipulates the environment of the target in order to induce an incorrect cognitive representation and, as a result, a desired behavior" (Johar \& Venkataramani, 1995).

From the above definitions, certain characteristics of deception appear to be homogeneous:

1. Deception occurs between two parties involved in a social exchange, namely the deceiver and the target of the deception;

2. Deception is an intentional or deliberate act;

3. Deception is accomplished by manipulating the environment of the social exchange (with information being part of this environment);

4. Deception has an instrumental end purpose, i.e. to induce certain perceptual and/or behavioural changes in the target that would not otherwise have been feasible, and;

5. Deception is not a means in itself (Jacoby J. A., 1975).

\section{Literature Review}

Advertising is basically a type of communication. It attempts to persuade potential customers to purchase or consume a product or service. It is designed in such a way that it creates and reinforces brand image and brand loyalty. Thus, advertising plays a very important role in forming consumer behaviour (Aaker D. A., 1974). Advertising is usually important for triggering the first time purchase of the product. Then, if the consumer likes it, he will purchase the product again. However, if the advertising and promotion portrays a good image of the product, the repurchase of the product is guaranteed (Aaker \& Myers, 1987).

Advertiser's primary mission is to reach prospective customers and influence their awareness, attitudes and buying behaviour. They spend a lot of money to keep individuals (markets) involved in their products. Marketers need to understand the buying behaviour of the consumers while designing their advertisements for the desired impact (Adkinson \& Mazis, 1976). Advertisements play an essential role in creating an image of a product in the minds of the consumers. Advertisements must be catchy and must communicate relevant information to the consumers (Armsrtong \& Russ, 1975). Advertising and promotion offer a news function to consumers. Viewers of ads learn about new products and services available to them, much like they learn about events in the news (Armstrong \& Mclennan, 1973).

Consumers have a rational response to advertising when they look at the features of a product or service. This response focuses on a logical listing of all the functional aspects of the offering. When customers weigh benefits, they become emotionally involved with advertising and promotion. Consumers identify different ways through which the product or service can make them happier, improve their lives or give them pleasure (Attas, 1999). This part of the consumer response is irrational and can lead to impulse buying and competition to obtain the product. Repeated advertising messages affect consumer behaviour (Bames, 1975). This repetition serves as a reminder to the consumer. Behaviour that stems from reminders includes suddenly thinking of a product while shopping and making a decision to buy it, as if it had 
been on the consumer's "to-do" list (Bauer \& Greyser, 1968). Consumer behaviour splits between loyalty and alienation depending on how well the product lives up to its advertised benefits. Corporate behaviour - such as scandals or charity work - can also affect alienation and loyalty responses (Beauchamp, 1984). Once the consumer makes this choice, advertising and promotion are not likely to undo that decision.

According to the critics, "Advertising manipulates us to buy things we don't need by playing on our emotions. The persuasive techniques are so powerful that consumers are helpless to defend themselves" (Boddewyn, 1982). The defense says that advertising cannot make us buy things we do not need; that people who say the opposite have little respect for consumers' common sense and their ability to make decisions; that many advertised products fail; that subliminal advertising, which has inspired many fears among critics, has never been proven effective; and that some products are successful even without advertising (Calfee \& Ringold, 1994). In short, advertising's influence has been exaggerated. People are skeptical and do not pay that much attention to advertising (Calfee \& Ringold, 1994).

To the complaint that "Advertising is deceptive", it must be said that continued deception would be self-defeating because it causes consumers to turn against a product (Lutz, 1985). 'Puffery' -- "the best", "greatest", "premier" -- if sometimes believed, is therefore deceptive, but there is little evidence that deceptive advertising helps sales. It is in the interest of the advertiser to stay honest (Permut, 1973).

Deception can be through various ways: price deception, product deception, advertising deception, quality deception, etc. Out of all of these, deceptive advertising is the most commonly used way of deceiving the consumers. Throughout the nineteenth and early twentieth century, the world came under the assault of deceptive advertising. Experimental researchers tend to rely on consumer perceptual evidence to assess deceptive advertising claims (Chaouachi \& Rached, 2012). In practice, both scholars and practitioners may face challenges to prove advertising deceptiveness technically. Indeed, the extent to which consumers can be deceived may depend upon a mix of intrinsic and extrinsic factors. Sometimes the relationships among these factors can be ambiguous, intertwined, and subtle (Lee, 2007). Therefore, under what circumstances consumers are more or less susceptible to deceptive advertising has become a focal issue of interest for experimental researchers. This study is restricted to TV commercial advertising of "detergent powders in India".

\subsection{Deceptive Advertising}

Deceptive advertising has long been condemned as unethical and harmful to consumers (Aaker D. A., 1974). Being misled by an advertisement, consumers may respond negatively not only to further advertising from the same deceptive source but also to advertising from other marketers (Armsrtong \& Russ, 1975). These effects are broad in their impact and generalize to advertisers from different geographic regions, different kinds of products, and different types of advertising claims (Olson \& Dover, 1978). They are also powerful in that the deceptive advertising undermines the effectiveness of subsequent marketing communications, even when the advertised product offers strong benefits or carries a well-known brand (Zhihong, 2008). The negative effects of ad deception are also relatively long 
lasting in the sense that they are observed for additional advertisements, encountered 24 hours after the initial deception.

The researchers found that advertising deception evokes self-protective goals, motivating people to minimize the possibility of being fooled again (Carson, Wokutch, \& Cox, 1985). This occurs through two distinct processes. First, when exposed to new advertisements from the source that previously deceived them, consumers actively counter argue the advertiser's claims. Second, when the new advertisements come from another marketer, deception operates by activating negative stereotypes about advertising in general, which reduces the persuasive impact of subsequent advertisements (Konslow, 2000).

In marketing literature, only a few authors have tried to define deception in advertising (Aaker, David, \& A., 1974), and they too have not been able to develop a well-accepted definition. The courts have generally proclaimed that the Federal Trade Commission (FTC) has expert judgment in deceptive advertising cases, and often determined the existence of deception based on FTC interpretations of how consumers might interpret an advertisement (Maronick, 1991).

Deception in advertising is far from a new concern. Traditionally, courts have been quite lenient and have tended to hold that the consumer should have examined the goods, in question, more adequately or that the advertisements merely represented "matters of opinion" and should have been treated with skepticism. If an advertisement (or advertising campaign) leaves the consumer with (an) impression(s) and/or belief(s) different from what would normally be expected if the consumer had reasonable knowledge, and that impression(s) and/or belief(s) is factually untrue or potentially misleading, then deception is said to exist (FTC, 1983). Deception in advertising needs further definition and procedures for measurement. Gardner's conceptual approach offers suggestions for both common understanding of deception that focuses on the consumer. An advertisement is deceptive if it causes a significant percentage of potential consumers (i.e., those at whom it is directed or whose consumption behavior is likely to be influenced by it) to have false beliefs about the product (Gardner, 1975) (Goa, 2008).

\section{FTC Statement}

The FTC's October 1983 policy statement focused on three necessary elements for an ad to be deemed deceptive (Carruthers \& Jill):

1. There must be a representation, omission, or practice that is likely to mislead the consumer

2. It must be material, i.e., potentially directly or indirectly impacting purchase behaviour (e.g., by influencing salient beliefs) and

3. The ad must be evaluated from the perspective of the consumer acting reasonably in the circumstances (Kinnear \& Root, 1988).

It has been interpreted to imply that an ad is not deceptive unless it deceives consumers acting reasonably or the reasonable consumer (Preston, 1976). It was originally deemed impractical to protect all consumers (Rosch, 1975), based on the belief that a minority might misinterpret and thus be misled by deceptive information (Gardner D. M., The Role of Marketing research in Public Policy decision Making, 1974). Thus, a selective enforcement standard was set to protect reasonable (but not less than reasonable) consumers (Ford G. T. and Calfee, 1986). 


\subsection{Perceived Deception}

The consumer's belief, held without sufficient evidence to warrant certainty, that the PRA (product recommendation agents) i.e., salesmen or advertisers, is being deceptive (Byrd Bredbenner, Grasso, \& Darlene, 2001). This study focuses on the notion of perceived deception because perceptions have been consistently found to be stronger predictors in determining individuals' attitude and behaviour. Like many marketing concepts, perception is derived from the discipline of psychology (Permut, 1973). In the generic sense, perception is the process of gathering information by sensing its surroundings (Permut, 1973). Three stages of exposure, attention and interpretation make up the process of perception. A narrow but commonly adopted understanding of perception in marketing often refers to a consumer's interpretation of an object, which is the final stage of the perception process.

In line with previous studies, a narrow definition of perception has been adopted in this paper. Perception has long been recognised as the most significant barrier to effective communication. Past research suggests that it cannot be said that information from the sender (marketer) will definitely get through to the receiver (consumer) (Anderson, Rolph, Marvin, \& Jolson, 1980), since correct decoding of marketing information hinges on the consumer's perception of the communication content. People respond on the basis of their perception of reality, not the reality per se (Rosch, 1975). It has been argued that consumer behaviour is, at root, driven by perceptions of a brand even if they are misconceptions of actual events (Percy, 1980). It has also been widely recognised that it is perception that provides the grounds for purchasing decisions (Fry, July, 1974).

In this study, perception is operationalized using product or service image, since by definition product or service image is "how a product or service image is perceived by consumers" (Alford \& Sherrell, 1996). As such, perceived product image is in fact the consumers' perceptions of a product. (Sawyer, 1976) asserts that there are three primary components of a product's image. These are the physical elements/attributes (e.g. green in colour), the functional characteristics/benefits or consequences of using a product (e.g. do not need to wash hair so often), and the brand personality (e.g. cheerful) (Estrada, 2006). Branded products are often purchased based not only on functional or utilitarian attributes, but also for symbolic reasons (Ford G. T. and Calfee, 1986). The brand personality dimension tends to serve a symbolic or self- expressive function and, in contrast, product-related attributes tend to serve a utilitarian function for consumers (Welti \& Belinda, 1983). This is more likely to be the case with "hi- visible" luxury BP, where some personal or social meaning is to be attached to the branded product.

\subsection{The Deceptive Impact of an Ad}

A belief is a subjective probability of a relationship existing between two concepts, and forms the basis of attitudes (Kuehl \& Robert, 1977). For example, the copy point, "Brand X detergent cleans clothes," suggests a relationship between Brand X detergent and clean clothes, with the strength of that relationship being reflected in the subjective probability that the relationship is true. Beliefs form the basis of attitude in that an attitude is a function of the sum of the subjective probabilities that certain outcomes will occur (bi) weighted by the evaluation of those outcomes (Fishbein \& Ajzen, 1975). (While "attributes" should only be used in reference to the 
product and "outcomes" in reference to its purchase, the terms will be used interchangeably to improve readability.) Beliefs may be salient or non-salient. A salient belief (or a belief related to a salient belief) is a belief that affects behavioural intention and behaviour (Jacoby \& Small, 1972). For example, the degree to which a housewife believes that Detergent $\mathrm{X}$ cleans clothes is almost certain to affect her buying intention. A non-salient belief does not affect intention. Therefore, the degree to which the housewife believes that Detergent $\mathrm{X}$ is made in the U.S.A. is not likely to have an effect on her intention.

It is unclear a priori whether advertising in general, and deceptive statements in particular, increase the purchase of washing products (cooperative effects), or simply increase market share for the advertised brand without increasing overall consumption (competitive or predatory effects). It is possible that exposure to nondeceptive ads and exposure to deceptive ads could have different effects. Because we consider this to be an empirical question, we do not have a strong a priori hypothesis about whether exposure to non-deceptive or deceptive ads has cooperative or competitive effects.

\section{Antecedents of Perceived Deception}

\begin{tabular}{|l|l|l|}
\hline \multicolumn{1}{|c|}{ Consumer Related } & \multicolumn{1}{|c|}{ Product Related } & \multicolumn{1}{c|}{ Ad Related } \\
\hline Consumer Demographics & $\begin{array}{l}\text { Type of Attributes } \\
\text { Search; Credence; } \\
\text { Experience }\end{array}$ & $\begin{array}{l}\text { Ad related type of } \\
\text { Claims }\end{array}$ \\
\hline $\begin{array}{l}\text { Consumer Attitude } \\
\text { Knowledge; Level of Awareness; Consumer } \\
\text { Susceptibility }\end{array}$ & $\begin{array}{l}\text { Attitude towards the } \\
\text { Brand }\end{array}$ & $\begin{array}{l}\text { Message } \\
\text { Involvement }\end{array}$ \\
\hline
\end{tabular}

\subsubsection{Consumer Characteristics}

Previous research has documented a number of individual differences in how consumers tend to respond to advertising claims. These intrinsic differences can be either dispositional or developmental.

\subsubsection{Demographics Attributes}

(Carruthers \& Jill, 2004) argue that age is an indicative factor. Also, there is severity of memory-based and knowledge-based deficits when consumers process advertising information. More specifically, (Heslop, Mar., 1985) find that young adults are less susceptible to certain misleading techniques than older adults, not because they are more capable of distinguishing truthful claims from misleading implications, but due to the tendency of younger people to be more engaged in the process of scrutinizing advertisements.

Developmental differences can be attributed to a socialisation processes whereby consumers learn to cope with deceptive persuasion effectively (Koller \& Salzberger, 2007). According to (Jacoby J. a., 1975), consumer knowledge structure and inferential abilities evolve from the perceptual stage (3-7 years), through the analytical stage (7-11 years), and to the reflective stage (11-16 years). Consumer 
susceptibility to deceptive claims varies depending upon the different life stages from early childhood to adulthood (Brandt \& Ivan L., 1977).

Additionally, gender can also be a factor. (Heslop, Mar., 1985) reveal that gender moderates susceptibility to "copy x copy" interactions in erroneous inferences. Males are more susceptible than females in general, but female nonusers of the product are more susceptible than male nonusers (Ford, Kuehl, \& Reksten, 1975).

\subsubsection{Consumer Knowledge}

There have been countless studies detailing cases of deceptive advertising and the effects caused by it. In addition to creating a higher turnover, and raised cash flow, deceptive advertising brings with it a great deal of unexpected social consequences (Armstrong \& Mclennan, 1973). According to (L., Manipulative Advertising, 1984) businesses are constantly trying to make their product as appealing as possible to their potential customers. In the process of making their products more appealing to customers, unrealistic (or confusing) numbers or terms are sometimes used. To businesses this translates to greater profits, whereas to the consumer this same action can cause a great deal of dissatisfaction and sometimes even injury (Davis, 1994). The relationship between customer loyalty and deceptive advertisements remains a shady area.

Another method of deceiving consumers is providing too much information or information that is completely false (Newell, Goldsmith, \& Banzhaf, 1998). According to (Anderson, Rolph, Marvin, \& Jolson, 1980), the amount of money spent on advertising is increasing so rapidly because advertising is what it informs the consumer of a product, and what a consumer is informed of, is what the consumer will make their decision on.

There exists a relatively strong debate regarding the ethics behind deceptive marketing. Some people seem to allow it while others are fighting passionately for the government to pass regulations to prevent it from occurring (Knauer, 1973). Interestingly enough, businesses seem to be pro-deceptive marketing while groups of consumers have often rallied against it. This leads many to believe that the solution is to train costumers to discern misleading advertising from the truth (Carson, Wokutch, \& Cox, 1985). The FTC would be the most likely candidate to provide this education, but it is currently unable to educate consumers to the degree necessary for their protection (Attas, 1999).

\subsubsection{Level of Awareness}

A critical issue in consumer education is whether perceptions of unfair marketing practices are related to consumer complaint behavior. One reason that the issue is important, concerns remedial action. If consumers' complaint behaviors are affected by their awareness of unfair marketing practices, then a strategy of consumer education is most appropriate (Cronin, Brady, \& Hult, 2000). Increasing consumer knowledge of unfair marketing practices should lead to increased complaint behavior when such practices are encountered (Kindra, Laroche, \& Muller, 1994). Additionally, educating consumers in the methods of forming and presenting complaints about grievances becomes an important associated issue. These strategies have many advocates (Anderson, Rolph, Marvin, \& Jolson, 1980), although at least some persons active in the area question the effectiveness of consumer education 
programs in increasing consumer knowledge or in altering their behavior (Pollay, 1969). If consumer perceptions of unfair marketing practices are unrelated to their complaint behavior, that is, if barriers exist which prevent consumers from taking action or consumers cannot be instructed effectively, and then regulatory action by public agencies may be the most appropriate direction for protecting consumers from unfair marketing practices. This approach essentially says that what consumers cannot or will not do for themselves must be done by regulatory agencies (Percy, 1980).

\subsubsection{Consumer Susceptibility}

Consumer susceptibility to advertising refers to "the extent to which individuals attend to and value commercial messages as sources of information for guiding their consumptive behaviors" (Barr \& Kellaris, 2000, pp. 230). In the context of deceptive advertising, susceptibility refers to the extent to which consumers are more or less likely to acquire false information, form misperceptions, and engage in consumptive behaviors to their detriment (Bearden, Netemeyer, \& Teel, 1990).

Consumer susceptibility to deceptive advertising has been a growing area of study since the 1980s. Specific topics include

1. the conditions under which consumers can or cannot recognize deceptive claims

2. the psychological mechanisms and ramifications of being deceived

3. The effects of regulatory remedies (Bearden, Netemeyer, \& Teel, 1990).

\subsubsection{Product Related Effects}

As originally conceptualized in cognitive psychology, expertise refers to a superior ability to solve problems within a given subject area (Carson, Wokutch, Richard, \& James E. Cox, 1985). Market researchers have adhered to a similar view. For example, product expertise has been associated with superior ability to process incoming product information (Jacoby J. a., 1975) and defined as a capacity to perform product-related tasks successfully.

\subsubsection{Search, Experience, and Credence Claims}

(Edell, 1983) contributed the idea that certain qualities can never be verified by the average consumer. This occurs because the consumer may not possess sufficient technical expertise to assess the product's true performance, to diagnose his/her own need for the product or service, or because diagnosing a need separately from filling the need at the same time is uneconomical or difficult. These qualities were termed "credence".

(Nelson P., Jul.-Aug., 1974) Some researchers based their work on economics of information theory by considering how different types of attributes interact with consumer search and trial. (Johar \& Venkataramani, 1995) distinguish between search and experience attributes. Search attributes are ones that can be verified prior to purchase through direct inspection or readily available sources. Experience attributes are ones that can be verified only after use of the product (Anderson, Rolph, Marvin, \& Jolson, 1980). Credence attributes are ones that are difficult to verify even after use (Albers-Millers, 1999). Branded products have been shown to be perceived as higher in quality than unbranded products (Hegarty, 1978). 


\subsubsection{Attitude towards the Brand}

To make good decisions, it is often helpful to understand why the group that will be affected by those decisions behaves in the way it does (Fishbein M. , 1967). The attempt to understand behaviour brings us to consideration of attitudes. An attitude is 'a predisposition to act in a particular way.' Knowing attitudes can therefore be useful in predicting what people are likely to do, as well as explaining what they have done (Bolton \& Drew, 1991). Indeed, it was the belief that individuals with favourable attitude towards products or services were more likely to buy them, that led to the importance of attitude measurement as a method of data collection. Unfortunately for decision makers, attitudes do not operate quite this simply or directly in influencing behaviour (Tankha, 1998). Strong personal or social influences may cause an individual not to act in accordance with his or her general attitude (Homer \& Kahle, 1988). When the behaviour is relatively unimportant to the individual, he or she may act first and form an attitude later, based on the outcome of the action. However, for actions that are costly or important to the individual, there is evidence that attitudes often precede behaviour (Olson \& Zanna, 1993). Hence, the management decision maker's interest is there in attitude measurement. (Fishbein \& Ajzen, 1975)

Attitude $=$ Cognitive component: what the individual knows or believes about an object or act

Affective component: what the individual feels emotionally about an object or act

Conative component: how the individual is disposed to behave towards an object or act

An important assumption of attitude measurement techniques is that attitudes are multidimensional. That is to say, we notice more than one aspect about most objects, and decisions to buy are often a compromise between the different aspects that make up our attitudes (De Matos, Ituassu, \& Rossi, 2007). The researcher is interested in uncovering all the relevant aspects of attitude towards a particular brand or service, and identifying which one will be the most important in a particular choice situation (Petty \& Cacioppo, 1986). For this reason, attitude measurement often involves the use of scales that measures many dimensions of the attitudes to the same object. Attitude towards the brand on the basis of the advertisement of the product or service influences the consumer's perceived deception towards the brand as well as the product (Ruiz, Arcas, \& Cuestas, 2001).

\subsubsection{Ad Claims}

Advertising claims are the verbal messages that convey material information about product or service attributes. Over the years, researchers have developed a number of typologies. (Gardner D. M., 1974) argues that advertising deceptiveness results from unconscionable lies, claim-fact discrepancies, and claim-belief interactions. (Rosch, 1975) refine these categories as fraud, falsity, and misleadingness. Fraud refers to blatant lies with a deliberate intention to cheat; falsity focuses on nonfactual information (Johnson, Grazioli, \& Jamal, 1993); and misleadingness occurs when the literal claims can be true but consumers draw erroneous inferences and form misperceptions. 


\section{Unconscionable Lie}

To be classified as deceptive in this category, an advertisement would make a claim that is completely false. There would be no way for consumers to achieve the claimed benefits (Graziolo \& Jarvenpaa, 2000).

\section{Claim-Fact Discrepancy}

An advertisement would be classified as deceptive in this category if some qualification must be placed upon the claim for it to be properly understood and evaluated. If the claimed benefits are only available to those consumers who use the product in a given manner, with proper precautions, or if the consumer can only understand the claim if he knows the exact information on which it was based, a claim-fact discrepancy exists (Castelfranchi \& Falcone, 1999).

\section{Claim-Belief Interaction}

Deceptive advertising classified as "claim-belief interaction" is that in which an advertisement or advertising campaign interacts with the accumulated attitudes and beliefs of the consumer in such a manner as to leave a deceptive belief or attitude about the product or service being advertised, without making either explicit or implied deceptive claims. It should be reiterated that the three categories of deception outlined above are not distinct. There is a good deal of overlap (Martin, 1996).

To apply this logic to consumer deception, it must first be recognized that most promotional strategies attempt either to change existing beliefs about a product and brand (i.e., how these beliefs are evaluated) or to introduce a new belief or make an existing belief more salient or important (Graziolo \& Jarvenpaa, 2000).

\subsubsection{Message Involvement and Message Acceptance}

Research indicates that persons differing in message attention and brand evaluation intent are apt to process message information in alternative ways. More involved individuals tend to make greater use of message arguments, while less involved persons are more apt to rely on peripheral information such as message source, brand names, package designs and product category labels (Singhapakdi, 1990).

Deceptive ad claims are often plausible and attribute-based (Olson \& Jerry, 1978). When exposed to such claims, more-involved receivers are apt to be more positively influenced because they focus more on the message for brand evaluation purposes, than less-involved receivers. When receivers link the message to personal experiences (are more involved) and the message content is plausible, the brand will be more positively evaluated. Because of intensity and direction of their attention, more-involved receivers are likely to allocate more processing capacity to the message and engage in more critical analysis of claims (Rao, 1974). Such analysis is apt to be accompanied by more cognitive responses to the message than the ones which would occur if the receiver was less involved (Sawyer, 1976). Assuming plausible and attribute-based arguments (which may vary in level of objective content), cognitive responses are likely to be predominantly positive or supportive (Edell, 1983). Thus, more involvement with such messages should result in greater message acceptance. 


\subsection{Behavioural Effects of Perceived Deception}

The various effects, when a consumer is exposed to a deceptive advertising or perceives the advertising to be deceptive, are as follows:-

1. product recall

2. ad recall

3. product preference

4. word of mouth

5. repurchase probability

\subsubsection{Product Recall}

Thus, message processing seems to depend on receivers' ability to comprehend and evaluate claims (Rosch, 1975); consumers are more likely to accept incoming advertising information that is compatible with their product- related cognitive schemata. As (L., Manipulative Advertising, 1984) explains, results of message processing depend on the amount and type of knowledge an individual has and the memory schema that is activated during message exposure (Chaiken, 1980). This follows from the notion that message processing entails relating incoming information to existing knowledge structures.

As (Wilkie \& William, 1973) notes, the nature of cognitive responses to a message depends on how well the information fits existing structures in memory. If information fits an activated memory schema (is understandable and plausible), support argumentation and acceptance are more apt to occur. If it does not fit, this is less likely to happen and confusion or counter argumentation may result (Allard, 2001). This suggests expertise is apt to influence cognitive responses and acceptance of ad messages (Chaiken \& Eagly, 1976). Because experts have more highly developed product-related schemata, they are apt to have greater ability to process messages presented in attribute-based terms (regardless of the level of objective content) (Grewal, Gotlieb, \& Marmorstein, 1994). Such messages, if plausible, are apt to generate more positive message-related cognitive responses from more expert receivers (Jones, Sinclair, \& Courneya, 2003). Non-experts have less ability to process the type of information in attribute-based ads because their frames of reference are more limited.

\subsubsection{Ad Recall}

Many studies have focused on examining the relationship between recall and ads. (Shimp, 1981) suggest that recall is quite suitable for measuring the effectiveness of ads, and (Telser \& Lester, 1964)states that recall is extensively adopted for evaluating the influence of ads. (Rosch, 1975) found that good recall performance counts on the correspondence between input information in ads and their output cues. (V., Wongtada, \& Kieschnick, 1996) also found that ads could produce various types of memory traces; for instance, messages presented in the ad that are connected to its attribute (e.g., tones of the ad or the medium used), content (e.g., purpose of the ad), and the product work. The audience, in other words, will have a better recall if the information is consistent with the main spirit of the ad itself. According to the definition of deceptive claims, however, the output of the perceptual process is distinct from the truth of the reality after the audience views the ad (Aaker, David, \& A., 1974). The common perspective is that a deceptive claim reduces the memory 
trace and causes bad recall. Moreover, (Nagler \& Matthew, 1993) suggests that factual claims are recalled more frequently than deceptive claims.

\subsubsection{Product Preferences}

Consumers when exposed to deception tend to reduce their product preferences towards the deceptive product or service (Heilman, Bowman, \& Wright, 2000).

\subsubsection{Word of Mouth Communication (WOM)}

Purchase decisions may also be based on the level of information available to customers. Information could come from family, peers, friends, relatives, sales personnel, advertising, etc. (Shimp, 1981). Two persons making a purchase at one point of purchase may have different levels of information with them (Stauss, 1997). In economics, information asymmetry deals with the study of decisions in transactions where one party has more or better information than the other (Goldsmith, 2006).

\subsubsection{Repurchase Probability}

Consumers when exposed to deception with regard to a particular brand, or product, or service tend to form an image in their minds for the respective brand, or product, or service (Lee, Eze, \& Ndubisi, 2011). They probably tend to form a negative image about the product, which then leads to negative repurchase probability (Keaveney, Huber, \& Herrmann, 2007).

\section{Research Methodology}

The present study falls under the statistical category of descriptive research where primary data is used to describe the nature of perceived deception with various behavioural aspects. Primary data consisting of response to structured, non-disguised questionnaire is used to test the hypothesized relationship. It is a repeated crosssectional survey, in which each wave is an independently drawn multistage stratified probability sample of females. An individual level data, collected from New Delhi, was conducted during the months of February 2019 to November 2019. Due care has been taken during the sampling process to ensure sufficient representation of respondents from different socio-economic, age, education and occupation groups. In order to minimize respondents' fatigue and to test their recall level, the data are collected in several phases. In phase 1, demographic data and data regarding unaided recall on detergent powder was collected. During phase 2, respondents were shown the screenshots of three TV commercials of detergent powders and were asked to recall the brand name of those advertisements and give their responses on various questions related to the recall. In phase 3, respondents were given 10 questions in a questionnaire to rate on various scales regarding the three TV commercials i.e. TIDE, NIRMA, WHEEL. Likert scale was used to test the consumer's perception. It was 5 point likert scale i.e. agree strongly, agree slightly, neither agree nor disagree, disagree slightly, and disagree strongly.

Detergent Products were selected on the basis of complaint forum data published by Advertising and Standards Council of India (ASCI) during 2010 to 2013. ASCI which was established in 1985, is committed to the cause of self-regulation in advertising and ensuring the protection of the interests of consumers. ASCI was 
formed with the support of all four sectors connected with Advertising, viz. Advertisers, Advertising Agencies, Media (including Broadcasters and the Press) and others like PR Agencies, Market Research Companies etc. It is the dedicated work put in by this group of highly respected people that has given tremendous impetus to the work of ASCI and the movement of self- regulation in the advertising. The products chosen in this study violates some important ASCI acceptable norms. By taking variety of products, the idea is to allow for more veracity in response to the instance of perceived deception and its related variables.

A total of about 350 questionnaires were distributed to sample population in the selected geographical region. Sample comprised of potential consumers for the chosen product categories. Respondents provided information about a host of demographic characteristics such as age, gender, race, marital status, number of children, and census region, and socioeconomic characteristics such as education, income, and employment status. They were asked to report their view points on various questions regarding the purchase behaviour, their frequency of purchases on the bases of various attributes, and regarding the purchase decisions.

\section{TV Commercials}

Advertisements were selected from the Advertising database (ADS). Ads that aired from 20015 to 2018 on national networks and cables were used. Their snapshots were taken and were used for the aided questions in the questionnaire. In fact, the description of the whole story of the ad was also included. Following two techniques were also used for this research paper

\section{Semantic Differential Scaling}

The data from semantic differential scaling can also be plotted on two dimensions simultaneously, showing how competing products, brands or services relate to each other in the consumer's mind. This technique can be computer based to make multidimensional maps of consumer's positioning of products, and is called 'perceptual mapping' (Chaouachi \& Rached, 2012).

\section{Thematic Apperception}

Thematic apperception tests are usually referred to as 'TATs' or 'picture interpretation'. The individual is shown a picture and is asked to say what is going on in the picture, what happened just beforehand and what will happen next, or is asked to tell a story based on the picture (Crouch \& Housden, 2003) to help respondents recall in a better way.

\section{Objectives of the Study}

The objectives of the study intended to be pursued are:

1. To access various aspects of perceived deception on consumers in detergent powder market.

2. To identify the basis of customer perception about deceptive advertising.

3. To find out antecedent conditions of consumers perceived deception.

4. To find out the behavioural effects of consumer perceived deception.

5. To find out difference in perceived deception across variable demographic groups. 


\section{Hypothesis}

H1: Perceived deception differs for difference in age, gender and education.

H2: Perceived deception differs for differences in role of attributes in purchase decision.

H3: Deceptive claim influences ad recall and product recall.

H4: Perceived deception and influence of advertisement are negatively related.

H5: Consumer perceiving deception is less likely to repurchase the product.

\section{Analysis}

The analysis of this research paper has been done on SPSS 20, and MS-Excel. The issue of missing values has been taken care of. All the questions in the questionnaire are covered in these dimensions on the basis of their applicable dimension to which they are best suited. Dimensions were established on: - Perceived Deception; Ad and product recall; Influential advertisement; Deceptive claims; Role of attributes towards purchase decision; Frequency of purchase.

\subsection{Reliability}

Reliability is a measuring instrument which tests the consistency of results. To check each dimension's strength, reliability test has been conducted and significant results having Cronbach's alpha of 0.5 and above were recorded. Here, the Cronbach's alpha for perceived deception as a dimension is 0.916, which shows excellent reliability among the variables included. The Cronbach's alpha for ad and product recall is 0.442 among the variables included. For influential advertisement, 0.510 falls in the acceptable range. The Cronbach's alpha for deceptive claims is 0.557 which is acceptable for the variables included. The dimension's strength for role of attributes is 0.768 which is a very good reliability among the variables included. Lastly, the Cronbach's alpha for frequency of purchase is 0.493 , which falls in the acceptable range for reliability among the variables included. After the testing of reliability among the various dimensions, the summated score for each dimension was calculated for further testing and analysis.

Table 6.1: Reliability Statistics

\begin{tabular}{|l|c|c|c|}
\hline \multicolumn{1}{|c|}{ Dimension } & \multicolumn{3}{c|}{ Cronbach's Alpha } \\
\hline Dimension & $\begin{array}{c}\text { Cronbach's } \\
\text { Alpha }\end{array}$ & $\begin{array}{c}\text { Cronbach's Alpha Based on } \\
\text { Standardized Items }\end{array}$ & N of Items \\
\hline Perceived Deception & .916 & .912 & 28 \\
\hline Ad and Product Recall & .442 & .543 & 7 \\
\hline Influential Advertisements & .510 & .359 & 12 \\
\hline Deceptive Claims & .557 & .481 & 6 \\
\hline Role of attributes & .768 & .757 & 14 \\
\hline Frequency of purchase & .493 & .648 & 7 \\
\hline
\end{tabular}

\subsection{ANOVA Analysis}

Analysis of variance (abbreviated as ANOVA) is essentially a procedure for testing the difference among different groups of data for homogeneity. Hence, it is a method 
of analyzing the variance to which a response is subject into its various components corresponding to various sources of variation. If the significance value of ANOVA is less than 0.05 , then it is said to be acceptable. In this study, we have tested each demographic against each dimension. The results are here as under:-

Table 6.2 Anova Analysis: Gender

\begin{tabular}{|c|c|c|c|c|c|c|}
\hline Dimension & & Sum of Squares & df & Mean Square & $\mathbf{F}$ & Sig. \\
\hline Perceived Deception & $\begin{array}{l}\text { Between Groups } \\
\text { Within Groups } \\
\end{array}$ & $\begin{array}{c}.068 \\
79.283 \\
\end{array}$ & \begin{tabular}{|c|}
1 \\
241 \\
\end{tabular} & $\begin{array}{l}.068 \\
.329 \\
\end{array}$ & .207 & .650 \\
\hline Ad and Product Recall & $\begin{array}{l}\text { Between Groups } \\
\text { Within Groups } \\
\end{array}$ & \begin{tabular}{|c|}
.156 \\
18.421 \\
\end{tabular} & $\begin{array}{c}1 \\
231 \\
\end{array}$ & $\begin{array}{l}.156 \\
.080 \\
\end{array}$ & 1.960 & .163 \\
\hline \begin{tabular}{|l|} 
Influential \\
Advertisements \\
\end{tabular} & $\begin{array}{l}\text { Between Groups } \\
\text { Within Groups } \\
\end{array}$ & $\begin{array}{c}.049 \\
23.253 \\
\end{array}$ & \begin{tabular}{|c|}
1 \\
241 \\
\end{tabular} & $\begin{array}{l}.049 \\
.096 \\
\end{array}$ & .507 & .477 \\
\hline Deceptive Claims & $\begin{array}{l}\text { Between Groups } \\
\text { Within Groups } \\
\end{array}$ & $\begin{array}{c}.212 \\
143.809 \\
\end{array}$ & \begin{tabular}{|c|}
1 \\
241 \\
\end{tabular} & $\begin{array}{l}.212 \\
.597 \\
\end{array}$ & .355 & .552 \\
\hline Role of Attributes & $\begin{array}{l}\text { Between Groups } \\
\text { Within Groups } \\
\end{array}$ & $\begin{array}{c}.417 \\
47.277 \\
\end{array}$ & \begin{tabular}{|c|}
1 \\
241 \\
\end{tabular} & $\begin{array}{l}.417 \\
.196 \\
\end{array}$ & 2.124 & .146 \\
\hline Frequency of Purchase & $\begin{array}{l}\text { Between Groups } \\
\text { Within Groups } \\
\end{array}$ & $\begin{array}{c}.400 \\
117.234\end{array}$ & \begin{tabular}{|c|}
1 \\
241 \\
\end{tabular} & $\begin{array}{l}.400 \\
.486\end{array}$ & .822 & .366 \\
\hline
\end{tabular}

This table 6.2 shows that there is $65 \%$ significant difference in the mean of Perceived Deception and Gender as a demographic factor. Hence, 65\% variation is explained. Similarly, $16 \%$ significant difference in the mean of Ad and product recall and gender as a demographic factor; $47 \%$ significant difference in the mean of influential advertisement and gender as a demographic factor; 55\% significant difference in the mean of deceptive claim and gender as a demographic factor. Hence, $55 \%$ variation is explained in this dimension by the independent variable, gender. Also, there is $14 \%$ significant difference in the mean of role of attributes and gender as a demographic factor. Lastly, there is $36 \%$ significant difference in the mean of frequency of purchase and gender as a demographic factor. Hence, $36 \%$ variation is explained in this dimension by the independent variable, gender.

Table 6.3 Anova Analysis: Age

\begin{tabular}{|c|c|c|c|c|c|c|}
\hline Dimension & & Sum of Squares & df & Mean Square & $\mathbf{F}$ & Sig. \\
\hline Perceived Deception & \begin{tabular}{|l|} 
Between Groups \\
Within Groups
\end{tabular} & $\begin{array}{c}2.774 \\
76.578\end{array}$ & \begin{tabular}{|c|}
6 \\
236 \\
\end{tabular} & $\begin{array}{l}.462 \\
.324\end{array}$ & 1.425 & .206 \\
\hline Ad and Product Recall & \begin{tabular}{|l|} 
Between Groups \\
Within Groups \\
\end{tabular} & $\begin{array}{c}.206 \\
18.371 \\
\end{array}$ & \begin{tabular}{|c|}
6 \\
226 \\
\end{tabular} & $\begin{array}{l}.034 \\
.081 \\
\end{array}$ & .423 & .863 \\
\hline Influential Advertisements & \begin{tabular}{|l|} 
Between Groups \\
Within Groups \\
\end{tabular} & $\begin{array}{c}.888 \\
22.413 \\
\end{array}$ & \begin{tabular}{|c|}
6 \\
236 \\
\end{tabular} & $\begin{array}{l}.148 \\
.095 \\
\end{array}$ & 1.559 & .160 \\
\hline Deceptive Claims & $\begin{array}{l}\text { Between Groups } \\
\text { Within Groups }\end{array}$ & $\begin{array}{c}14.841 \\
129.179\end{array}$ & \begin{tabular}{|c|}
6 \\
236 \\
\end{tabular} & $\begin{array}{c}2.474 \\
.547\end{array}$ & 4.519 & .000 \\
\hline Role of Attributes & \begin{tabular}{|l|} 
Between Groups \\
Within Groups \\
\end{tabular} & $\begin{array}{r}3.103 \\
44.591 \\
\end{array}$ & \begin{tabular}{|c|}
6 \\
236 \\
\end{tabular} & $\begin{array}{l}.517 \\
.189 \\
\end{array}$ & 2.737 & .014 \\
\hline Frequency of Purchase & $\begin{array}{l}\text { Between Groups } \\
\text { Within Groups }\end{array}$ & $\begin{array}{c}14.917 \\
102.717\end{array}$ & \begin{tabular}{|c|}
6 \\
236
\end{tabular} & $\begin{array}{c}2.486 \\
.435\end{array}$ & 5.712 & .000 \\
\hline
\end{tabular}


Table 6.3 shows that there is $20 \%$ significant difference in the mean of Perceived deception and age as a demographic factor. Hence, $20 \%$ variation is explained in this dimension by the independent variable, age. There is $86 \%$ significant difference in the mean of ad and product recall and age as a demographic factor; $16 \%$ significant difference in the mean of influential advertisement and age as a demographic factor. There exists $0 \%$ significant difference in the mean of deceptive claim and age as a demographic factor. Hence, $0 \%$ variation is explained in this dimension by the independent variable, age. Moreover, a 1\% significant difference in the mean of role of attributes and age as a demographic factor is explained in this dimension by the independent variable, age. Lastly, there is $0 \%$ significant difference in the mean of frequency of purchase and age as a demographic factor. Hence, $0 \%$ variation is explained in this dimension by the independent variable, age.

Table 6.4 Anova Analysis: Marital Status

\begin{tabular}{|c|c|c|c|c|c|c|}
\hline Dimension & & $\begin{array}{c}\text { Sum of } \\
\text { Squares }\end{array}$ & df & $\begin{array}{c}\text { Mean } \\
\text { Square }\end{array}$ & $\mathbf{F}$ & Sig. \\
\hline Perceived Deception & $\begin{array}{l}\text { Between Groups } \\
\text { Within Groups }\end{array}$ & $\begin{array}{c}1.563 \\
77.789\end{array}$ & $\begin{array}{c}1 \\
241\end{array}$ & $\begin{array}{l}1.563 \\
.323\end{array}$ & 4.842 & .029 \\
\hline $\begin{array}{l}\text { Ad and product } \\
\text { recall }\end{array}$ & $\begin{array}{l}\text { Between Groups } \\
\text { Within Groups }\end{array}$ & $\begin{array}{c}.005 \\
18.572\end{array}$ & $\begin{array}{c}1 \\
231\end{array}$ & $\begin{array}{l}.005 \\
.080\end{array}$ & .067 & .796 \\
\hline $\begin{array}{l}\text { Influential } \\
\text { Advertisements }\end{array}$ & $\begin{array}{l}\text { Between Groups } \\
\text { Within Groups }\end{array}$ & $\begin{array}{c}.710 \\
22.592\end{array}$ & $\begin{array}{c}1 \\
241\end{array}$ & $\begin{array}{l}.710 \\
.094\end{array}$ & 7.575 & .006 \\
\hline Deceptive Claims & $\begin{array}{l}\text { Between Groups } \\
\text { Within Groups }\end{array}$ & $\begin{array}{c}1.863 \\
142.158\end{array}$ & $\begin{array}{c}1 \\
241\end{array}$ & $\begin{array}{l}1.863 \\
.590\end{array}$ & 3.158 & .077 \\
\hline Role of Attributes & $\begin{array}{l}\text { Between Groups } \\
\text { Within Groups }\end{array}$ & $\begin{array}{c}1.044 \\
46.650\end{array}$ & $\begin{array}{c}1 \\
241\end{array}$ & $\begin{array}{l}1.044 \\
.194\end{array}$ & 5.392 & .021 \\
\hline $\begin{array}{l}\text { Frequency of } \\
\text { Purchase }\end{array}$ & $\begin{array}{l}\text { Between Groups } \\
\text { Within Groups }\end{array}$ & $\begin{array}{c}.128 \\
117.506\end{array}$ & $\begin{array}{c}1 \\
241\end{array}$ & $\begin{array}{l}.128 \\
.488\end{array}$ & .262 & 609 \\
\hline
\end{tabular}

Table 6.4 shows that there is $2 \%$ significant difference in the mean of perceived deception and marital status as a demographic factor. Hence, $2 \%$ variation is explained in this dimension by the independent variable, marital status. Also, there is $79 \%$ significant difference in the mean of ad and product recall and marital status as a demographic factor. Hence, $79 \%$ variation is explained in this dimension by the independent variable, marital status. A $0 \%$ significant difference in the mean of influential advertisement and marital status as a demographic factor is explained in this dimension by the independent variable, marital status. There is $7 \%$ significant difference in the mean of deceptive claim and marital status as a demographic factor; $2 \%$ significant difference in the mean of role of attributes and marital status as a demographic factor; $60 \%$ significant difference in the mean of frequency of purchase and marital status as a demographic factor. Hence, $60 \%$ variation is explained in this dimension by the independent variable, marital status. 
Table 6.5 Anova Analysis: Working Status

\begin{tabular}{|c|c|c|c|c|c|c|}
\hline Dimension & & Sum of Squares & df & Mean Square & $\mathbf{F}$ & Sig. \\
\hline Perceived Deception & \begin{tabular}{|l|} 
Between Groups \\
Within Groups \\
\end{tabular} & $\begin{array}{c}366 \\
78.985 \\
\end{array}$ & \begin{tabular}{|c|}
1 \\
241 \\
\end{tabular} & $\begin{array}{l}.366 \\
.328 \\
\end{array}$ & 1.118 & .291 \\
\hline Ad and Product Recall & \begin{tabular}{|l|} 
Between Groups \\
Within Groups \\
\end{tabular} & $\begin{array}{c}.047 \\
18.531\end{array}$ & \begin{tabular}{|c|}
1 \\
231 \\
\end{tabular} & $\begin{array}{l}.047 \\
.080\end{array}$ & .585 & .445 \\
\hline Influential Advertisements & $\begin{array}{l}\text { Between Groups } \\
\text { Within Groups }\end{array}$ & $\begin{array}{c}.760 \\
22.541\end{array}$ & $\begin{array}{c}1 \\
241\end{array}$ & $\begin{array}{l}.760 \\
.094\end{array}$ & 8.130 & .005 \\
\hline Deceptive Claims & \begin{tabular}{|l|} 
Between Groups \\
Within Groups \\
\end{tabular} & $\begin{array}{c}7.211 \\
136.810 \\
\end{array}$ & \begin{tabular}{|c|}
1 \\
241 \\
\end{tabular} & $\begin{array}{l}7.211 \\
.568 \\
\end{array}$ & 12.702 & .000 \\
\hline Role of Attributes & \begin{tabular}{|l|} 
Between Groups \\
Within Groups \\
\end{tabular} & $\begin{array}{c}1.367 \\
46.327 \\
\end{array}$ & \begin{tabular}{|c|}
1 \\
241 \\
\end{tabular} & $\begin{array}{l}1.367 \\
.192 \\
\end{array}$ & 7.109 & .008 \\
\hline Frequency of Purchase & $\begin{array}{l}\text { Between Groups } \\
\text { Within Groups }\end{array}$ & $\begin{array}{c}6.125 \\
111.509 \\
\end{array}$ & \begin{tabular}{|c|}
1 \\
241 \\
\end{tabular} & $\begin{array}{l}6.125 \\
.463\end{array}$ & 13.237 & .000 \\
\hline
\end{tabular}

Table 6.6 Anova Analysis: Occupation

\begin{tabular}{|c|c|c|c|c|c|c|}
\hline Dimension & & Sum of Squares & df & Mean Square & $\mathbf{F}$ & Sig. \\
\hline Perceived Deception & $\begin{array}{l}\text { Between Groups } \\
\text { Within Groups }\end{array}$ & $\begin{array}{c}3.786 \\
75.566\end{array}$ & \begin{tabular}{|c|}
3 \\
239
\end{tabular} & $\begin{array}{c}1.262 \\
.316\end{array}$ & 3.991 & .008 \\
\hline Ad and Product Recall & \begin{tabular}{|l|} 
Between Groups \\
Within Groups \\
\end{tabular} & $\begin{array}{c}.072 \\
18.506 \\
\end{array}$ & \begin{tabular}{|c|}
3 \\
229 \\
\end{tabular} & $\begin{array}{l}.024 \\
.081 \\
\end{array}$ & .296 & .829 \\
\hline Influential Advertisements & $\begin{array}{l}\text { Between Groups } \\
\text { Within Groups }\end{array}$ & $\begin{array}{c}1.853 \\
21.448\end{array}$ & \begin{tabular}{|c|}
3 \\
239
\end{tabular} & $\begin{array}{l}.618 \\
.090\end{array}$ & 6.884 & .000 \\
\hline Deceptive Claims & $\begin{array}{l}\text { Between Groups } \\
\text { Within Groups }\end{array}$ & $\begin{array}{c}13.896 \\
130.124\end{array}$ & \begin{tabular}{|c|}
3 \\
239
\end{tabular} & $\begin{array}{c}4.632 \\
.544\end{array}$ & 8.508 & .000 \\
\hline Role of Attributes & \begin{tabular}{|l|} 
Between Groups \\
Within Groups \\
\end{tabular} & $\begin{array}{c}1.701 \\
45.993 \\
\end{array}$ & \begin{tabular}{|c|}
3 \\
239 \\
\end{tabular} & $\begin{array}{l}.567 \\
.192 \\
\end{array}$ & 2.947 & .034 \\
\hline Frequency of Purchase & $\begin{array}{l}\text { Between Groups } \\
\text { Within Groups }\end{array}$ & $\begin{array}{c}8.539 \\
109.095\end{array}$ & \begin{tabular}{|c|}
3 \\
239
\end{tabular} & $\begin{array}{c}2.846 \\
.456\end{array}$ & 6.235 & .000 \\
\hline
\end{tabular}

Table 6.5 depicts that there is $29 \%$ significant difference in the mean of perceived deception and working status as a demographic factor; $44 \%$ significant difference in the mean of ad and product recall and working status as a demographic factor; $0 \%$ significant difference in the mean of influential advertisement and working status as a demographic factor, deceptive claim and working status as a demographic factor, role of attributes and working status as a demographic factor. Hence, $0 \%$ variation is explained in this dimension by the independent variable, working status.

This table shows that there is $0 \%$ significant difference in the mean of perceived deception and occupation as a demographic factor, of influential advertisement and occupation as a demographic factor, and of deceptive claim and occupation as a demographic factor of deceptive claim and occupation as a demographic factor of deceptive claim and occupation as a demographic factor, and frequency of purchase and occupation as a demographic factor. Hence, $0 \%$ variation is explained in this dimension by the independent variable, occupation. Also, there is $82 \%$ significant difference in the mean of ad and product recall and occupation as a demographic factor. Hence, $82 \%$ variation is explained in this dimension by the independent variable, occupation. Lastly, there is $3 \%$ significant difference in the mean of role of 
attributes and occupation as a demographic factor. Hence, $3 \%$ variation is explained in this dimension by the independent variable, occupation.

Table 6.7 Anova Analysis: Qualification

\begin{tabular}{|c|c|c|c|c|c|c|}
\hline Dimension & & $\begin{array}{l}\text { Sum of } \\
\text { Squares }\end{array}$ & df & $\begin{array}{c}\text { Mean } \\
\text { Square }\end{array}$ & $\mathbf{F}$ & Sig. \\
\hline Perceived Deception & $\begin{array}{l}\text { Between Groups } \\
\text { Within Groups }\end{array}$ & $\begin{array}{c}3.587 \\
75.764\end{array}$ & $\begin{array}{c}3 \\
239\end{array}$ & $\begin{array}{c}1.196 \\
.317\end{array}$ & 3.772 & .011 \\
\hline Ad and Product Recall & $\begin{array}{l}\text { Between Groups } \\
\text { Within Groups }\end{array}$ & $\begin{array}{c}.360 \\
18.218\end{array}$ & $\begin{array}{c}3 \\
229\end{array}$ & $\begin{array}{l}.120 \\
.080\end{array}$ & 1.509 & .213 \\
\hline $\begin{array}{l}\text { Influential } \\
\text { Advertisements }\end{array}$ & \begin{tabular}{|l} 
Between Groups \\
Within Groups
\end{tabular} & $\begin{array}{c}.463 \\
22.839\end{array}$ & $\mid \begin{array}{c}3 \\
239\end{array}$ & $\begin{array}{l}.154 \\
.096\end{array}$ & 1.614 & .187 \\
\hline Deceptive Claims & \begin{tabular}{|l} 
Between Groups \\
Within Groups
\end{tabular} & $\begin{array}{c}14.198 \\
129.823\end{array}$ & $\mid \begin{array}{c}3 \\
239\end{array}$ & $\begin{array}{l}4.733 \\
.543\end{array}$ & 8.712 & .000 \\
\hline Role of Attributes & \begin{tabular}{|l} 
Between Groups \\
Within Groups
\end{tabular} & $\begin{array}{c}.739 \\
46.955\end{array}$ & $\mid \begin{array}{c}3 \\
239\end{array}$ & $\begin{array}{l}.246 \\
.196\end{array}$ & 1.254 & .291 \\
\hline $\begin{array}{l}\text { Frequency of } \\
\text { Purchase }\end{array}$ & \begin{tabular}{|l} 
Between Groups \\
Within Groups
\end{tabular} & $\begin{array}{l}25.551 \\
92.084\end{array}$ & $\mid \begin{array}{c}3 \\
239\end{array}$ & $\begin{array}{c}8.517 \\
.385\end{array}$ & 22.105 & .000 \\
\hline
\end{tabular}

Table 6.7 shows that there is $1 \%$ significant difference in the mean of perceived deception and qualification as a demographic factor. Hence, $1 \%$ variation is explained in this dimension by the independent variable, qualification. There is $21 \%$ significant difference in the mean of ad and product recall and qualification as a demographic factor. Hence, $21 \%$ variation is explained in this dimension by the independent variable, qualification. And there is $18 \%$ significant difference in the mean of influential advertisement and qualification as a demographic factor. Interestingly, there is $0 \%$ significant difference in the mean of deceptive claim and qualification as a demographic factor, and between frequency of purchase and qualification as a demographic factor. Hence, $0 \%$ variation is explained in this dimension by the independent variable, qualification. Lastly, 29\% significant difference in the mean of role of attributes and qualification as a demographic factor is explained in this dimension by the independent variable, qualification.

Table 6.8 shows that there is $79 \%$ significant difference in the mean of perceived deception and family income as a demographic factor. Hence, $79 \%$ variation is explained in this dimension by the independent variable, family income. There is $30 \%$ significant difference in the mean of ad and product recall and family income as a demographic factor; $62 \%$ significant difference in the mean of influential advertisement and family income as a demographic factor; $2 \%$ significant difference in the mean of deceptive claim and family income as a demographic factor; $1 \%$ significant difference in the mean of role of attributes and family income as a demographic factor; and $31 \%$ significant difference in the mean of frequency of purchase and family income as a demographic factor. Hence, $31 \%$ variation is explained in this dimension by the independent variable, family income. 
Table 6.8 Anova Analysis: Family Income

\begin{tabular}{|c|c|c|c|c|c|c|}
\hline Dimension & & Sum of Squares & df & Mean Square & $\mathbf{F}$ & Sig. \\
\hline Perceived Deception & $\begin{array}{l}\text { Between Groups } \\
\text { Within Groups }\end{array}$ & $\begin{array}{c}.325 \\
72.096\end{array}$ & \begin{tabular}{|c|}
3 \\
224
\end{tabular} & $\begin{array}{l}.108 \\
.322\end{array}$ & .337 & .799 \\
\hline Ad and Product Recall & $\begin{array}{l}\text { Between Groups } \\
\text { Within Groups }\end{array}$ & $\begin{array}{c}.297 \\
17.514\end{array}$ & \begin{tabular}{|c|}
3 \\
214 \\
\end{tabular} & $\begin{array}{l}.099 \\
.082\end{array}$ & 1.208 & .308 \\
\hline \begin{tabular}{|l|} 
Influential \\
Advertisements \\
\end{tabular} & \begin{tabular}{|l|} 
Between Groups \\
Within Groups \\
\end{tabular} & $\begin{array}{c}.176 \\
22.211 \\
\end{array}$ & \begin{tabular}{|c|}
3 \\
224 \\
\end{tabular} & $\begin{array}{l}.059 \\
.099 \\
\end{array}$ & .592 & .621 \\
\hline Deceptive Claims & \begin{tabular}{|l|} 
Between Groups \\
Within Groups \\
\end{tabular} & $\begin{array}{c}5.793 \\
131.290 \\
\end{array}$ & \begin{tabular}{|c|}
3 \\
224 \\
\end{tabular} & $\begin{array}{l}1.931 \\
.586 \\
\end{array}$ & 3.294 & .021 \\
\hline Role of Attributes & $\begin{array}{l}\text { Between Groups } \\
\text { Within Groups }\end{array}$ & $\begin{array}{c}1.998 \\
41.524 \\
\end{array}$ & \begin{tabular}{c|}
3 \\
224 \\
\end{tabular} & $\begin{array}{l}.666 \\
.185\end{array}$ & 3.592 & .014 \\
\hline Frequency of Purchase & $\begin{array}{l}\text { Between Groups } \\
\text { Within Groups }\end{array}$ & $\begin{array}{c}1.759 \\
109.498\end{array}$ & \begin{tabular}{c|}
3 \\
224
\end{tabular} & $\begin{array}{l}.586 \\
.489\end{array}$ & 1.199 & .311 \\
\hline
\end{tabular}

This shows that there is $6 \%$ significant difference in the mean of perceived deception and family structure as a demographic factor. Hence, 65\% variation is explained in this dimension by the independent variable, family structure. There is $43 \%$ significant difference in the mean of ad and product recall and family structure as a demographic factor; 19\% significant difference in the mean of influential advertisement and family structure as a demographic factor; 98\% significant difference in the mean of deceptive claim and family structure as a demographic factor; $66 \%$ significant difference in the mean of role of attributes and family structure as a demographic factor; $1 \%$ significant difference in the mean frequency of purchase and family structure as a demographic factor. Hence, $1 \%$ variation is explained in this dimension by the independent variable, family structure. Therefore, our hypothesis, perceived deception differs for differences in age, gender and education is partially supported as we have proved that perceived deception differs for difference in education, marital status, occupation and family structure.

Table 6.9 Anova Analysis: Family Structure

\begin{tabular}{|c|c|c|c|c|c|c|}
\hline Dimension & & Sum of Squares & df & Mean Square & $\mathbf{F}$ & Sig. \\
\hline Perceived Deception & \begin{tabular}{|l|} 
Between Groups \\
Within Groups \\
\end{tabular} & $\begin{array}{c}1.119 \\
78.232 \\
\end{array}$ & \begin{tabular}{|c|} 
\\
241 \\
\end{tabular} & $\begin{array}{c}1.119 \\
.325 \\
\end{array}$ & 3.448 & .065 \\
\hline Ad and Product Recall & \begin{tabular}{|l|} 
Between Groups \\
Within Groups \\
\end{tabular} & $\begin{array}{c}.049 \\
18.528 \\
\end{array}$ & \begin{tabular}{|c|}
1 \\
231 \\
\end{tabular} & $\begin{array}{l}.049 \\
.080 \\
\end{array}$ & .615 & .434 \\
\hline Influential Advertisements & \begin{tabular}{|l|} 
Between Groups \\
Within Groups
\end{tabular} & $\begin{array}{c}.166 \\
23.136\end{array}$ & $\begin{array}{c}1 \\
241 \\
\end{array}$ & $\begin{array}{l}.166 \\
.096\end{array}$ & 1.725 & .190 \\
\hline Deceptive Claims & \begin{tabular}{|l|} 
Between Groups \\
Within Groups \\
\end{tabular} & $\begin{array}{c}.000 \\
144.020 \\
\end{array}$ & \begin{tabular}{|c|}
1 \\
241 \\
\end{tabular} & $\begin{array}{l}.000 \\
.598 \\
\end{array}$ & .001 & .980 \\
\hline Role of Attributes & \begin{tabular}{|l|} 
Between Groups \\
Within Groups \\
\end{tabular} & $\begin{array}{c}.038 \\
47.656 \\
\end{array}$ & \begin{tabular}{|c|}
1 \\
241 \\
\end{tabular} & $\begin{array}{l}.038 \\
.198 \\
\end{array}$ & .194 & .660 \\
\hline Frequency of Purchase & \begin{tabular}{|l|} 
Between Groups \\
Within Groups
\end{tabular} & $\begin{array}{c}5.513 \\
112.121\end{array}$ & \begin{tabular}{c|}
1 \\
241
\end{tabular} & $\begin{array}{l}5.513 \\
.465\end{array}$ & 11.850 & .001 \\
\hline
\end{tabular}




\subsection{Correlation}

The correlation has been tested among each variable with its corresponding variables one by one using Karl Pearson's simple correlation. The result of the test is shown in the table as under

Table 6.10 Correlation Analysis

\begin{tabular}{|l|l|c|c|c|}
\hline \multicolumn{2}{|l|}{} & N & Correlation & Sig. \\
\hline Pair 1 & d1: perceived deception \& d2: ad and product recall & 233 & .111 & .090 \\
\hline Pair 2 & d1: perceived deception \& d3: influence of ad & 243 & .613 & .000 \\
\hline Pair 3 & d1: perceived deception \& d4: deceptive claim & 243 & .548 & .000 \\
\hline Pair 4 & d1: perceived deception \& d5: role of attributes & 243 & .465 & .000 \\
\hline Pair 5 & d1: perceived deception \& d6: frequency of purchase & 243 & .629 & .000 \\
\hline Pair 6 & d2: ad and product recall \& d3: influence of ad & 233 & .135 & .040 \\
\hline Pair 7 & d2 : ad and product recall \& d4: deceptive claim & 233 & -.004 & .948 \\
\hline Pair 8 & d2: ad and product recall \& d5: role of attributes & 233 & .051 & .443 \\
\hline Pair 9 & d2: ad and product recall \& d6: frequency of purchase & 233 & .133 & .043 \\
\hline Pair 10 & d3: influence of ad \& d4: deceptive claims & 243 & .446 & .000 \\
\hline Pair 11 & d3: influence of ad \& d5: role of attributes & 243 & .432 & .000 \\
\hline Pair 12 & d3: influence of ad \& d6: frequency of purchase & 243 & .479 & .000 \\
\hline Pair 13 & d4: deceptive claims \& d5: role of attributes & 243 & .372 & .000 \\
\hline Pair 14 & d4: deceptive claims \& d6: frequency of purchase & 243 & .458 & .000 \\
\hline Pair 15 & d5: role of attributes \& d6: frequency of purchase & 243 & .277 & .000 \\
\hline
\end{tabular}

The correlation test shown in table 6.10 explains that there is 0.11 positive correlation between perceived deception and ad product recall with 0.09 significance. On the other hand, there exists 0.61 positive correlation between perceived deception and influence of ad with 0.00 significance level. Pair 3 shows 0.54 positive correlation between perceived deception and deceptive claim with 0.00 significance. Pair 4 shows 0.46 positive correlation between perceived deception and role of attributes with 0.00 significance. Pair 5 shows 0.62 positive correlations between perceived deception and frequency of purchase with 0.00 significance. Pair 6 shows that there is 0.13 positive correlation between ad product recall and influence of ad with 0.40 as significant value. Pair 7 shows that there is 0.04 negative correlation between ad product recall and deceptive claim with 0.94 significance. Pair 8 shows that there is 0.05 positive correlation between ad product recall and role of attributes with 0.44 significance. Pair 9 shows that there is 0.13 positive correlation between ad product recall and frequency of purchase with 0.04 significance. Pair 10 shows 0.44 positive correlation between influence of ad and deceptive claim with 0.00 significance. Pair 11 shows 0.43 positive correlation between influence of ad and role of attributes with 0.00 significance. Pair 12 shows 0.47 positive correlation between influence of ad and frequency of purchase with 0.00 significant. Pair 13 shows that there is 0.37 positive correlation between deceptive claim and role of attributes with 0.00 significance. Pair 14 shows 0.45 
positive correlation between deceptive claim and frequency of purchase with 0.00 significance. Pair 15 shows 0.27 positive correlation between role of attributes and frequency of purchase with 0.00 significance.

Therefore, our hypothesis; perceived deception differs for difference in role of attributes, stands accepted. However, another hypothesis, deceptive claim influences ad and product recall is not supported at all. Another hypothesis which states that perceived deception and influence of advertisement are negatively related is also not supported. As the results prove, the perceived deception and influence of advertisements are positively related. Hypothesis which states that consumer perceiving deception is less likely to repurchase the product stands accepted.

\section{Results and Discussion on Managerial Implications}

This study aims to extend the existing knowledge about the deceptive advertising phenomenon. Several theoretical implications can be drawn from it. It has long been recognized that advertising can fulfill two functions: provide information to consumers, and persuade or mislead consumers (Bagwell, 2007). This dual nature of advertising led Lester Telser to write that "Hardly any business practice causes economists greater uneasiness than advertising" (Telser L. G., 1964). This paper provides an empirical estimate of the effect of individual-level exposure to deceptive statements on the consumption of the advertised good and consumption of substitute goods.

The finding that deceptive advertising may have a net negative effect on consumption by women is relevant for public policy. The FTC has aggressively pursued deceptive advertising in the market for detergent powder products (Armstrong \& Mclennan, 1973). The fact that we find no evidence that deceptive advertising convinces consumers to take these products is good news for their clothes. This is not to say that the FTC should cease enforcing laws against deceptive advertising - it could still be doing harm by driving out products that are marketed relatively honestly and could be leading to long-term discouragement among consumers disappointed with their results - but the harms of deceptive advertising are not as great as if it convinced previously-abstaining consumers to begin consuming these ineffective and risky products (FTC, 1983).

This study provides tracks for further research directions. One would be to reexamine this model by gathering data in other geographical areas, taking into account influential cultural differences. The model could also be tested on products other than detergent powder to acquire knowledge about how generalizable the findings of this study are. As suggested in the previous section, different variables can be included into the attitude-behaviour models in order to improve the amount of variance explained. An interesting venue for further research would also be a longitudinal design of the study, enabling a more dynamic insight into the mechanisms of the non-deceptive purchase process.

\section{Limitations of the Study}

This approach has its limitations. One limitation is the construct of perceived deception instead of deception detection. Due to the method of study, the instrument was able to measure only individual's perceptions of deception. This is due to the 
fact that actual deception was not done to the respondents; instead, they were invoked to judge the validity of a message. By performing a longitudinal study, researchers would be able to measure factors such as disposition to trust, deception detection self-efficacy, etc., then train individuals against certain behaviour, and later evaluate whether they were susceptible to the deception. Another limitation is that, the study focused on a limited range of counterfeit products. Another limitation is that, there is measurement error in our estimates of exposure to advertising and deception. These measures of exposure are that it was uncertain that people would have seen all of the advertisements. For example, even if they report having read the entire questionnaire, they might have flipped by the page with the ad and never seen it. Likewise, even if they report having watched a specific TV show, they might have left the room when the advertisement happened to run. This measurement error likely results in attenuation bias in our estimates of the impact of advertising exposure. Another limitation is that even within categories of magazines and TV shows, there may be targeting of ads to women who (e.g.) watch one detergent instead of another. Despite these limitations, this paper provides the most direct evidence to date on the effect of deceptive advertising on consumption of the advertised good and its substitutes.

\section{References}

1. Aaker, David, \& A. (1974). Deceptive Advertising. (D.A.S., Ed.) Consumerism: Search for the Consumer Interest, 137-156.

2. Aaker, D. A., \& Myers, J. G. (1987). Advertising Management.

3. Adkinson, J. E., \& Mazis, M. B. (1976). An Experimental Evaluation of a Proposed Corrective Advertising Remedy. Journal of Marketing Research, 13, 178-183.

4. Albers-Millers, N. (1999). Consumer Misbehavior: Why People buy Illicit Goods. Journal of Consumer Marketing, 16(3), 273-87.

5. Alford, B., \& Sherrell, D. (1996). The Role of Affect in Consumer Satisfaction Judgments of Credence-based Services. Journal of Business Research, 37(1), 7184.

6. Allard, F. Kinesiology. 356 Course notes, University of Waterloo, Canada. Retrieved May 6, 2008, from Information processing in human perceptual motor performance: http://ahsmail.uwaterloo.ca/kin356/ illusion/direct.html

7. Anderson, Rolph, E., Marvin, A., \& Jolson. (1980). Technical Wording in Advertising: Implications for Market Segmentation. Journal of Marketing, Vol. 44 (winter), 57-66.

8. Armstrong, Gary, M., Kendall, C., \& Russ, F. A. (1975). Applications of Consumer Information Processing Research to Public Policy Issues. Communications Research, 2, 232-45.

9. Armstrong, G. M., \& Mclennan, J. P. (1973). The Federal Trade Commission and the Investigation and Regulation of Deception in Advertising; In Increasing Marketing Productivity/ Conceptual and Methodological Foundations of Marketing. (T. U. Geer, Ed.) American Marketing Association, 430-434.

10. Armstrong, M, G., N, M., Gurol, \& Frederick, R. A. (1980). Detecting and Correcting Deceptive Advertising: A Review and Evaluation. 17-39. 
11. Armstrong, M., G., Metin N., G., \& Frederick A., R. (1980). Defining and Measuring Deception in Advertising: A Review and Evaluation. (J. H. Martin, Ed.) Current Issues in Research in Advertising, 17-39.

12. Atkins, C., \& Block, M. (1983). Effectiveness of Celebrity Endorsers. Journal of Advertising Research, 23, 57-61.

13. Attas, D. (1999). What's Wrong with Deceptive Advertising? Journal of Business Ethics, 21(1), 49-60.

14. Bagwell, K. (2007). The Economic Analysis of Advertising. (M. A. Porter, Ed.) Handbook of Industrial Organization, 3.

15. Bames, J. G. (1975). The Communications Effect of Selected Retail Price Promotional Advertising Cues. Doctoral Dissertation. Toronto, Toronto.

16. Barens, \& G, J. (1975). Factors Influencing Consumer Reaction to Retail Newspaper 'SALE' Advertising. Combined Proceedings (pp. 471-477). Chicago: American Marketing Association.

17. Brandt, M. T., \& Ivan L., P. (1977, January). The Federal Trade Commission's Use of Evidence to Determine Deception. Journal of Marketing 47, 54-62.

18. Bauer, R. A., \& Greyser, S. A. (1968). Advertising in America: The Consumer View. Boston: Graduate School of Business Administration, Harvard University.

19. Bearden, W., Netemeyer, R., \& Teel, J. (1990). Further Validation of the Consumer Susceptibility to Interpersonal Influence Scale. Advances in Consumer Research, 17, 770-776.

20. Beauchamp T. L.: 1984, 'Manipulative Advertising', Business \& Professional Ethics Journal 3, 1-22.

21. Becker, B. W., \& Connor, P. E. (1981, May). Personal Values of the Heavy User of Mass Media. Journal of Advertising Research, 21, 37-43.

22. Boddewyn, J. J. (1982, winter). Advertising Regulation in the 1980s: The Underlying Global Forces. Journal of Marketing, 46, 27-35.

23. Bolton, R., \& Drew, J. H. (1991, January). A Longitudinal Analysis of the Impact of Service Changes on Customer Attitudes. Journal of Marketing, 55, 19.

24. Brown, G. H. (1952). Brand Loyalty- Fact or Fiction? Advertising Age, 23, 5355.

25. Byrd Bredbenner, C., Grasso, \& Darlene. (2001). The Effects of Food Advertising Policy on Televised Nutrient Content Claims and Health Claims. Family Economics and Nutrition Review, 13(1), 37-49.

26. Calfee, J. E., \& Ringold, D. J. (1994). The Seventy Percent Majority: Enduring Consumer Beliefs about Advertising. Journal of Public Policy and Marketing, 13, 228-238.

27. Campbell, M. C. (1995). When Attention-Getting Advertising Tactics Elicit Consumer Inferences of Manipulative Intent: The Importance of Balancing Benefits and Investments. Journal of Consumer Psychology, 4(3), 225-254.

28. Carlson, L., Grove, S. J., Kangun, N., \& Polonsky, J. M. (1996). An International Comparison of Environmental Advertising versus Associative Claims. Journal of Macro Marketing, 16(2), 57-68. 
29. Carruthers, \& Jill, N. (N.D.). The Use of Communications Research in the Determination of Misleading and Deceptive Advertising: A Literature Review. Working Paper Prepared for the Marketing Practices Branch.

30. Carson, T. L., Wokutch, R. E., \& Cox, J. E. (1985). An Ethical Analysis of Deception in Advertising. Journal of Business Ethics, 93-104.

31. Castelfranchi, C., \& Falcone, R. (1999). The Dynamics of Trust: From Beliefs to Action. Presented at Autonomous Agents 1999 Workshop on Deception, Fraud and Trust in Agent Societies, (Pp. 41-54). Seattle, WA.

32. Chaiken, S. (1980). Heuristic versus Systematic Information Processing and the Use of Source versus Message Cues in Persuasion. Journal of Personality and Social Psychology, 39, 752-766.

33. Chaiken, S., \& Eagly, A. H. (1976). Communication Modality as a Determinant of Message Persuasiveness and Message Comprehensibility. Journal of Personality and Social Psychology, 34(4), 605-614.

34. Chaouachi, S. G., \& Rached, K. S. (2012). Perceived Deception in Advertising: Proposition of a Measurement Scale. Journal of Marketing Research and Case Studies, 15.

35. Chi, \& Michelene, H. T. (1983). The Role of Knowledge on Problem Solving and Consumer Choice Behavior. (R. P. X, Ed.) Advances in Consumer Research, 567-571.

36. Cohen, D. (1972). Surrogate Indicators and Deception in Advertising. Journal of Marketing, 10-15.

37. Cohen, \& Dorothy. (July, 1972). Surrogate Indicators and Deception in Advertising. Journal of Marketing, 36, 10- 15.

38. Cohen, D. (Winter 1982). Unfairness in Advertising Revisited. Journal of Marketing 46, 77.

39. Commission, F. T. (1983, May 20). Policy Statement on Deception. Retrieved April 21, 2014, from http;//www.ftc.gov/bcp/policystmnt/ad-decept.htm.: http;//www.ftc.gov/bcp/policystmnt/ad-decept.htm.

40. Compeau, L. D., \& Grewal, D. (1998). Comparative Price Advertising: An Integrative Review. Journal of Public Policy and Marketing, 17(2), 257-273.

41. Compeau, Lary, D., Lindsey-Mullikin, J., Grewal, D., \& Ross, D. P. (2004). Consumer's Interpretations of the Semantic Phrases Found in Reference Price Advertisements. Journal of Consumer Affairs, 38(1), 178-87.

42. Cronin, J. J., Brady, M. K., \& Hult, G. T. (2000). Assessing the Effects of Quality, Value, and Customer Satisfaction on Consumer Behavioural Intentions in Service Encounters. Journal of Marketing, 56, 55-68.

43. Crouch, S., \& Housden, M. (2003). Attitude Measurement. In S. Crouch, \& M. Housden, Marketing Research for Managers (third ed., pp. 126-183). London: Butterworth-Heinemann Publications.

44. Davis, J. J. (1994, winter). Ethics in Advertising Decision-Making: Implications for Reducing the Incidence of Deceptive Advertising. The Journal of Deceptive Advertising, 2(2), 380-394.

45. De Matos, C. A., Ituassu, C. T., \& Rossi, C. A. (2007). Consumer Attitudes towards Counterfeits: A Review and Extension. Journal of Consumer Marketing, 24(1), 36-47. 
46. Dillion, T. (1973, October). What is Deceptive Advertising? Journal of Advertising Research, 13(5), 9-12.

47. Drake, P. R., \& Richie, R. J. (2007). The Defensive Consumer: Advertising Deception, Defensive Processing and Distrust. Journal of Marketing Research, 44(1), 114-127.

48. Edell, J. A. (1983). The Information Processing of Pictures in Print Advertisements. Journal of Consumer Research 10, 45-61.

49. Engel, J. E., Blackwell, R. D., \& Kegerreis, R. J. (1969). How Information is used to adopt an Innovation. Journal of Advertising Research, 9(4), 3-8.

50. Estrada, M. L. (2006). The Impact of Deceptive Advertising on Corporate Sales. Honors Thesis. Long Beach, CA: California University.

51. Estrada, M. L. (2006). The Impact of Deceptive Advertising on Corporate Sales. Honors thesis. California University, Long Beach, CA.

52. Fishbein, M. (1967). A Behavior Theory Approach to the Relations between Beliefs about an Object and the Attitude towards an Object. In M. Fishbein, \& M. Fishbein (Ed.), Attitude Theory and Model. New York: John Wiley and sons, 389-399.

53. Fishbein, M., \& Ajzen, I. (1975). Belief, Attitude, Intention, and Behavior: An Introduction to Theory and Research. MA: Addison-Wesley.

54. Ford G. T. and Calfee, J. E. (1986). Recent Developments in FTC on Deception. Journal of Marketing 50, 82-103.

55. Ford, G. T., Kuehl, P. G., \& Reksten, o. (1975). Classifying and Measuring Deceptive Advertising: An Experimental Approach. In M. M. Edward (Ed.), Combined Proceedings (pp. 493-497). Chicago: American Marketing Association.

56. Ford, G. T., Smith, D. b., \& Swasy, J. L. (1990). Consumer Skepticism of Advertising Claims: Testing Hypotheses from Economies of Information. Journal of Consumer Research, 16, 433-441.

57. Freeman, G. L., \& Moser, R. H. (2000). Consumer's Attitude towards Advertising by Chiropractors and their Use of various Media Practices. American Marketing Association, 1-11.

58. Friedmann, R., \& Zimmer, M. R. (1988). The Role of Psychological Meaning in Advertising. Journal of Advertising, 17(1), 31-40.

59. Friestad, \& Wright. (1995). Persuasion Knowledge lay People's and Researcher's Beliefs about the Psychology of Advertising. Journal of Consumer Research, 22(1), 62-74.

60. Fry, J. N. (July, 1974). Consumer Appraisal of Retail Price Advertisements. Journal of Marketing, 38, 64-74.

61. FTC. (1983). FTC. Retrieved May 21, 2016, from FTC: http://ftc.gov/bcp/policystmt/addecept.htm/

62. Gao, Z. (2008). Controlling Deceptive Advertising in China: An Overview. Journal of Public Policy and Marketing, 27, 165-177.

63. Gardner, D. M. (1973, June). Can Deceptive Advertising be measured? Working Paper series in Marketing Research, 18.

64. Gardner, D. M. (1974). The Role of Marketing Research in Public Policy Decision Making. Journal of Marketing 38, 38-47. 
65. Gardner, D. M. (1975). Deception in Advertising: A Conceptual Approach. Journal of Marketing 39, 40-46.

66. Goa, Z. (2008). Controlling Deceptive Advertising in China: An Overview. Journal of Public Policy and Marketing, 27(2), 165-177.

67. Goldsmith, R. E. (2006). Electronic Word of Mouth. In M. Khosrow-Pour (Ed.), Encyclopedia of E-commerce, E-Government and Mobile Commerce (pp. 408412). Hershey, PA: Idea Group publishing.

68. Graziolo, S., \& Jarvenpaa, S. L. (2000, July). Perils of Internet Fraud: An Empirical Investigation of Deception and Trust with Experienced Internet Consumers. IEEE Transactions on Systems, Man, and Cybernetics, 30(4), 395430.

69. Greer, T. V., \& Paul, R. T. (1985). Development of Standardized and Harmonized Advertising Regulation in the European Economic Community. Journal of Advertising, 14(2), 23-33.

70. Grewal, D., Gotlieb, J., \& Marmorstein, H. (1994). The Moderating Effects of Message Framing and Source Credibility on the Price Perceived Risk Relationship. Journal of Consumer Research, 145-153.

71. Grewal, D., Monroe, K. B., \& Krishnan, R. (1998). The Effects of Price Comparison Advertising on Buyer's Perceptions of Acquisition Value, Transition Value, and Behavioral Intentions. Journal of Marketing, 62(2), 46-59.

72. Gujrati, D., \& Smitha, A. (2004). Basic Econometrics (4th ed.). India: Tata McGraw-Hill.

73. Gurol, M. N. (1977). Deception in Advertising: A Review of Past and Current FTC Practice and an Experimental Evaluation of a New Approach for Eradicating Its Effects. Unpublished Ph.D. Dissertation. Graduate School of Business Administration, University of North Carolina, Chapel Hill.

74. Haefner, J. E. (1972). The Legal versus the Behavioral Meaning of Deception. (M. Venkateson, Ed.) Advances in Consumer Research 3, 356-360.

75. Haefner, J. E., Permut, S. E., \& Surlin, S. H. (1974). An Approach to the Evaluation of Deception in Television Advertising. Journal of Advertising, 3(4), 40-45.

76. Hardesty, D., Carlson, J., \& Bearden, W. (2002). Brand Familiarity and Invoice Price Effects on Consumer Evaluation: The Moderating Role of Skepticism toward Advertising. Journal of Advertising, 31(2), 1-15.

77. Hegarty, W. H. (1978). Some Determinates of Unethical Decision Behaviour: An Experiment. Journal of Applied Psychology, 63(4), 451-457.

78. Heilman, C. M., Bowman, D., \& Wright, G. P. (2000, May). The Evolution of Brand Preferences and Choice Behaviors of Consumers New to a Market. Journal of Marketing Research, 37, 139-155.

79. Heslop, J. L. (Mar., 1985). Reference Prices and Deception in Newspaper Advertising. Journal of Consumer Research, 11(4), 868-876.

80. Homer, P. M., \& Kahle, L. R. (1988, winter). A Structural Equation Test of the Value-Attitude-Behavior Hierarchy. Journal of Personality and Social Psychology, 54, 638-646.

81. Hunt, S. A. (1986). A General Theory of Marketing Ethics. Journal of Macro Marketing, 8, 5-16. 
82. Hyman, M. R., Tansey, R., \& Clark, J. W. (1994). Research on Advertising Ethics: Past, Present and Future. Journal of Advertising, 23(3), 5.

83. Jacoby, J., \& Small, C. (1972). The FDA Approach to Defining Misleading Advertising. Journal of Marketing, 65-73.

84. Johar, \& Venkataramani, G. (1995). Consumer Involvement and Deception from Implied Advertising Claims. Journal of Marketing Research, 32, 267-279.

85. Johnson, P. E., Grazioli, S., \& Jamal, K. (1993). Fraud Detection: Intentionality and Deception in Cognition. Accounting, Organization and Society, 18(5), 467488.

86. Jones, L. W., Sinclair, R. C., \& Courneya, K. S. (2003). The Effects of Source Credibility and Message Framing on Exercise Intentions, Behaviors, and Attitudes: An Integration of the Elaboration Likelihood Model and Prospect Theory. Journal of Applied Social Psychology, 33(1), 179-196.

87. Kangun, N., Carlson, L., \& Grove, S. J. (1991). Environmental Advertising Claims: A Preliminary Investigation. Journal of Public Policy and Marketing, 10(2), 47-58.

88. Keaveney, S. M., Huber, F., \& Herrmann, A. (2007). A Model of Buyer Regret: Selected Pre Purchase and Post Purchase Antecedents with Consequences for the Brand and the Channel. Journal of Business Research, 60(12), 1207-2015.

89. Keul, P. G. (1974). The Corrective Advertising Remedy of the FTC: an Experimental Evaluation. Journal of Marketing 38, 48-54.

90. Kindra, G., Laroche, M., \& Muller, T. (1994). Consumer Behaviour: A Canadian Perspective. Scarborough (2).

91. Kinnear, T. C., \& Root, A. R. (1988). The FTC and Deceptive Advertising in the 1980s: Are Consumers being adequately protected? Journal of Public Policy and Marketing, 40-48.

92. Knauer, V. (1973). Advertising and Consumerism. Journal of Advertising, 2(1), 6-8.

93. Koller, M., \& Salzberger, T. (2007). Cognitive Dissonance as a relevant Construct throughout the Decision-Making and Consumption Process: An Empirical Investigation related to a Package Tour. Journal of Consumer Behavior, 6(3), 217-227.

94. Konslow, S. (2000). Can the Truth Hurt? How Honest and Persuasive Advertising can unintentionally lead to Increased Consumer Skepticism. Journal of Consumer Affairs, 34(2), 16-32.

95. Kopalle, Praveen, K., \& Donald, R. L. (2006). Setting Quality Expectations When Entering a Market: What Should the Promise Be? Marketing Science, 25(1), 8-24.

96. Kottman, E. J. (1964). A Semantic Evaluation of Misleading Advertising. Journal of Communication, 151-156.

97. Kuehl, P. G., \& Robert, D. F. (1977). Brand Belief Measures in DeceptiveCorrective Advertising: An Experimental Assessment. (W. Perreault, Ed.) Advances in Consumer Research, 4, 373-379.

98. Kuehl, P. G. (1976). Brand Belief Measures in Deceptive Corrective Advertising: An Experimental Assessment. In K. Bernhardt (Ed.), Educator's conference. Chicago: American Marketing Association, 373-379. 
99. Kuehl, R. F. (Jan., 1974). The "Corrective Advertising" Remedy of the FTC: An Experimental Evaluation. Journal of Marketing, 38(1), 48-54.

100. Kuehn, A. (1962). Consumer Brand Choice as a Learning Process. Journal of Advertising Research, 2, 10-17.

101.L., B. T. (1984). Manipulative Advertising. Business and Professional Ethics Journal 3, 1-22.

102.LaTour, M. S., \& Henthorne, T. L. (1994). Ethical Judgments of Sexual Appeals in Print Advertising. Journal of Advertising, 23(3), 81-90.

103.Lee, C. H., Eze, U. C., \& Ndubisi, N. O. (2011). Analyzing Key Determinants of Online Repurchase Intentions. Asia Pacific Journal of Marketing and Logistics, 23(2), 200-221.

104.Lee, P. K. (2007). The Relationships among Self-Concept, Advertising, Brand Attitude and Purchase Intention: a Study of Domestic Vehicles. Unpublished Master's Dissertation. National Cheng Kung University, Tainan City.

105.Lipstein, B. (1959). The Dynamics of Brand Loyalty and Brand Switching. Proceedings of the Fifth Annual Conference of the Advertising Research Foundation. New York: Advertising Research Foundation, 101-108.

106.Lutz, R. (1985). Affective and Cognitive Antecedents of Attitude toward the Ad: A Conceptual Framework. In L. Alwitt, \& A. Mitchell, Psychological Processes and Advertising effects: Theory, Research and Application. Hillsdale, New Jersey: Lawrence Erlbaum Associates, 45-63.

107.M.R., H., R., T., \& W., C. J. (1994). Research on Advertising Ethics: Past, Present and Future. Journal of Advertising, 23(3), 5.

108. MacKenzie, S., Lutz, R., \& Belch, G. (1986). The Role of Attitude toward the Ad as a Mediator of Advertising Effectiveness: A Test of Competing Explanations. Journal of Marketing Research, 23(2), 130-143.

109. Maronick, T. J. (1991). Copy Tests in FTC Deception Cases: Guidelines for Researchers. Journal of Advertising Research, 31(6), 9-17.

110. Martin, F. (1996, May). Are Internet Fraud Fears Overblown? Credit Card Management, 9(2), 46-52.

111. Menon, S., \& Soman, D. (2002). Managing the Power of Curiosity for Effective Web Advertising Strategies. Journal of Advertising, 31(3), 1-14.

112. Mitchell, A. A., \& Olson, J. C. (1977). Cognitive Effects of Advertising Repetition. (W. D. Perreault, Ed.) Advances in Consumer Research, 4, 213-220.

113. Mitra, A. M., Raymond, A., \& Hopkins, C. D. (2008). Can Consumers Recognize Misleading Advertising Content in a Media Rich Online Environment? Psychology and Marketing, 25, 655-674.

114.Moog, C. (1990). Are they selling her Lips? New York: Morrow.

115.Nagler, \& Matthew, G. (1993). Rather Bait Than Switch: Deceptive Advertising with Bounded Consumer Rationality. Journal of Public Economics, 51, No. 3, 359-78.

116. Nelson, \& Philip. (1970). Information and Consumer Behaviour. Journal of Political Economy, 78(2), 311-329.

117.Nelson, \& Philip. (1974). Advertising as Information. Journal of Political Economy, 81, 729-754. 
118.Newell, S. J., Goldsmith, R. E., \& Banzhaf, E. J. (1998). The Effects of Misleading Environmental Claims on Consumer Perceptions of Advertising. Journal of Marketing Theory and Practice, 6(2), 48-60.

119. Obermiller, C., \& Spangenberg, E. (1998). Development of a Scale to Measure Skepticism toward Advertising. Journal of Consumer Psychology, 7(2), 159186.

120. Olson, \& Jerry, C. (1978). Cognitive Effects of Deceptive Advertising. Journal of Marketing Research, 15(1), 29-38.

121. Olson, J., \& Zanna, M. (1993). Attitudes and Attitude Change. Annual Review of Psychology, (44), 117-154.

122. Ormond, D., Warkentin, M., Marett, K., \& Johnston, A. C. (2011). Perceived Deception: An Evaluation of Technology Awareness and Self-Efficacy. IFIP, 121.

123. Oxford Concise Dictionary. (n.d.).

124.Penz, E., \& Stottinger, B. (2008). Original Brands and Counterfeit Brands- Do they have anything in common. Journal of Consumer Behaviour: An International Research Review, 2(7), 146-163.

125.Percy, L. a. (1980). Advertising Strategy: A Communication Theory Approach.

126.Permut, S. E. (1973). Perceived Deception in Television Advertising: A Factor Analytic Approach. 81st Annual Convention of the American Psychological Association, 817-818.

127.Petty, R. D. (1996). The Law of Misleading Advertising: An Examination of the Difference between Common and Civil Law Countries. International Journal of Advertising, 15(1), 33-37.

128.Petty, R. D. (1997, spring). Advertising Law in the United States and European Union. Journal of Public Policy \& Marketing, 16, 2-13.

129.Petty, R. D., \& Kopp, J. (1995). Advertising Challenges: A Strategic Framework and Current Review. Journal of Advertising Research, 35(2), 41-55.

130.Petty, R. E., \& Cacioppo, J. T. (1986). Communication and persuasion: Central and Peripheral routes to attitude change. New York, NY: Springer-Verlag.

131.Philip, A. D. (1978, February). Cognitive Effects of Deceptive Advertising. Journal of Marketing Research, 15, 29-38.

132.Pollay, R. W. (1969). Deceptive Advertising and Consumer Behaviour: A Case for Legislative and Judicial Reform. Kansas Law Review 17.

133.Prendergast, G., Liu, P.-y., \& Poon, D. T. (2009). A Hong Kong Study of Advertising Credibility. Department of Marketing Journal, 1-28.

134.Preston, I. L. (1976, July). A Comment on Defining Misleading Advertising and 'Deception in Advertising'. Journal of Marketing, 40, 54-57.

135.Preston, I. L. (1987). A Review of the Literature on Advertising Regulation. Current Issues and Research in Advertising, 10(1), 297-325.

136.Priester, J. R., \& Petty, R. E. (2003). The Influence of Spokesperson Trustworthiness on Message Elaboration, Attitude Strength, and Advertising Effectiveness. Journal of Consumer Psychology, 13(4), 408-421.

137.Puth, G., Mostert, P., \& Ewing, M. (1999). Consumer Perceptions of Mentioned Product and Brand Attributes in Magazine Advertising. Journal of Product and Brand Management, 8(1), 38-50. 
138.Rao, C. P. (1974). Southern Marketing Association Conference, (p. Deceptive Advertising: Consumer Concern and Evaluative Beliefs). Atlanta, G.A.

139.Reports, C. C. (1988). Deceptive Acts and Practices. No. 13, 205: 20911-29940.

140.Reynolds, T. J., \& Gutman, J. (1988, February/March). Laddering Theory, Method, Analysis, and Interpretation. Journal of Advertising Research, 28, 1134.

141.Roman, S. (2010). Relational Consequences of Perceived Deception in Online Shopping: The Moderating Role of Types of Product, Consumer's Attitude towards Internet, and Consumer's Demographics. Journal of Business Ethics, 373-391.

142.Romani, S. (2006). Price Misleading Advertising: Effects on Trustworthiness toward the Source of Information and Willingness to Buy. Journal of Product and Brand Management, 15(2), 130-138.

143. Rosch, T. J. (1975). Marketing Research and the Legal Requirements of Advertising. Journal of Marketing 39, 69-72.

144.Ruiz, S., Arcas, N., \& Cuestas, P. (2001). Consumer Attitudes towards Ecological Agrarian Fruits and Vegetables in Spain: A Segmentation Approach. Acta Horticulture.

145.Russo, J., Metcalf, B., \& Stephens, D. (1981). Identifying Misleading Advertising. Journal of Consumer Research, 8(2), 119-131.

146. Sacmmon, D. L., \& Mayer, R. N. (1991, June). Environmental Labeling and Advertising Claims: International Action and Policy Issues. Association for Consumer Research Summer Conference.

147.Sawyer, A. G. (1976). The Need to Measure Attitudes and Beliefs over Time: The Case of Deceptive and Corrective Advertising. In K. L. Bernhartdt (Ed.), Educator's Conference of the American Marketing Association. Chicago: American Marketing Association, 380-385.

148. Shimp, T. A. (1981, winter). Deceptive and Non deceptive Consequences of Evaluative Advertising. Journal of Marketing 45, 22-32.

149.Singhapakdi, A. a. (1990). Marketing Ethics: Factors Influencing Perceptions of Ethical Problems and Alternatives. Journal of Macro Marketing, 12, 4-18.

150. Stauss, B. (1997). Global Word of Mouth: Service Bashing on the Internet is a Thorny Issue. In Marketing Management.

151.Stern, P., Dietz, T., Abel, T., Guagnano, G. A., \& Kalof, L. (1999). A ValueBelief-Norm Theory of support for Social Movements: The Case of Environmentalism. Human Ecology Review, 2(6), 81-97.

152.Stokes, S. A. (2009). Deception in Environmental Advertising: Consumer's Reaction to Green Washing. Thesis. Manhattan, Kansas: Kansas State University.

153.Tankha, G. (1998). A Psychological Study of Attitudes and Awareness towards Environmental Pollution and Degradation. Unpublished Doctoral dissertation. Rajasthan University, Jaipur.

154.Tedlow, R. S. (1981). From Competitor to Consumer: The changing Focus of Federal Regulation of Advertising. Business History Review, 55(1), pp. 35-58.

155.Telser, \& Lester, G. (1964). Advertising and Competition. Journal of Political Economy, 72(6), 537-562. 
156.V., C. V., Wongtada, N., \& Kieschnick, R. L. (1996). Counterfeit Purchase Intentions: Role of Lawfulness Attitudes and Product Traits as Determinants. Journal of Business Research, 35, 41-53.

157.Wach, \& Wackman, D. B. (1973). Effects of Television Advertising on Consumer Socialization. Cambridge, MA: Marketing Science institute.

158. Webster's Dictionary. (n.d.).

159. Welti, \& Belinda. (1983). The Need for a Statutory Defining of 'Deceptive" Advertising. New England Law Review 19, 127-149.

160.Wilkie, \& William, L. (1973). Consumer Research and Corrective Advertising: A New Approach. MA: Marketing Science Institute.

161.Xiao, B., \& Tan, C. (2006). Reducing the Perceived Deception of Product Recommendation Agent: The Impact of Perceived Verifiability and Perceived Similarity. Proceedings of the Fifth Annual Workshop on HCI Research in MIS. Milwaukee, WI.

162.Xio, B., \& Tan, C. (2006). Reducing the Perceived Deception of the Product Recommendation Agent: The Impact of Perceived Verifiability and Perceived Similarity. Proceedings of 5th Annual Workshop on HCI Research in MIS. Milkwaukee, WI.

163.Zhihong, G. (2008). Controlling Deceptive Advertising in China: An Overview. Journal of Public Policy and Marketing, 27(2), 165-177.

\section{About Our Author}

Ishpreet Virdi is an Assistant Professor of Commerce at Mata Sundri College for Women, University of Delhi. She has done graduation, post-graduation and Doctor of Philosophy in Marketing from University of Delhi. Her research work focuses on Deceptive Advertising and its impact on Consumer Behaviour. She has significantly contributed several papers in leading journals and has presented papers at various conferences. More than 20 research papers in her name are published in reputed journals. To name a few, her research work was appreciated at IIM Lucknow conference in January 2017. Another one worth mentioning is in Journal of Business Studies of Department of Commerce, Shaheed Bhagat Singh College, University of Delhi. Lately, four of her research papers have been published in Scopus, UGC CARE listed Journals. Having a teaching experience of more than seven years in Commerce, she has also been accounted as a member of the team of paper setter in similar subjects. She is actively involved in research and consultancy in the areas of marketing and advertising. She has also delivered special lectures for the class of minority and weaker sections at various times and places. 